\section{Carbohydrate Metabolism and Efficiency of Photosystem II in Mown Creeping Bentgrass (Agrostis stolonifera L.)}

\author{
Mark J. Howieson and Nick Edward Christians ${ }^{1}$ \\ Department of Horticulture, Iowa State University, Ames, IA 50011
}

Additional index words. fructose, glucose, sucrose, double-cut, rolled, single-cut

\begin{abstract}
Regrowth of leaf tissue after mowing is necessary to form photosynthetic leaf area required for $\mathrm{CO}_{2}$ assimilation and plant growth and development. Leaf tissue regrowth often is dependent on levels of reserve carbohydrates stored in leaf sheaths and leaf bases. The objective of this study was to quantify mowing injury by measuring levels of fructan, sucrose, glucose, and fructose and efficiency of photosystem II (PSII) in notcut, rolled, single-cut, and double-cut creeping bentgrass (Agrostis stolonifera L.) grown in a greenhouse. Efficiency of PSII was reduced in double-cut grasses by as much as $9 \%$ compared with not-cut grasses. Fructan levels were reduced in single- and double-cut grasses compared with not-cut grasses by $52 \%$ and $45 \%$, respectively, $36 \mathrm{~h}$ after mowing. Glucose levels were $31 \%$ lower in double-cut grasses compared with not-cut grasses. No differences were observed in sucrose and fructose levels among not-cut, rolled, single-cut, and double-cut grasses. Mowing transiently reduced fructan and glucose levels in mowed grasses. Duration of reduction of fructan levels, magnitude of reduction in glucose levels, and efficiency of PSII were greatest in double-cut grasses, suggesting that multiple cuttings may be more damaging to plant vigor than single cutting.
\end{abstract}

Mowing removes leaf tissue that grasses use to acquire solar energy, thereby limiting photosynthesis and carbon assimilation (White, 1973). Regrowth and initiation of new leaf tissue after mowing is necessary to develop photosynthetic leaf area required for production of carbohydrates (Parsons et al., 1983). Rate of leaf tissue regrowth often depends on levels of carbohydrates present in grass tissue before defoliation, suggesting that plants rely on carbohydrate reserves to provide energy and raw materials to redevelop leaf and shoot tissue (Davidson and Mithorpe, 1966; Donaghy and Fulkerson, 1998; Morvan-Betrand et al., 1999).

The primary reserve carbohydrate of creeping bentgrass (Agrostis stolonifera L.) is fructan. Fructan is a polymer of fructose with a terminal glucose moiety (Chatterton et al., 1989). Increased catabolism and decreases in levels of fructans have been observed in grasses in response to defoliation (Morvan-Betrand et al., 2001; Prud'homme et al., 1992; Volenec, 1986). The magnitude of reduction in levels of reserve carbohydrates often is dependent on the severity of defoliation. In general, lower mowing heights and more frequent cuttings cause greater reductions in carbohydrate reserves (Donaghy and Fulkerson, 1998). Fructose hydrolyzed from fructan can be converted to the monosaccharide glucose by isomerase

Received for publication 11 Dec. 2006. Accepted for publication 20 Nov. 2007.

${ }^{1}$ To whom reprint requests should be addressed; e-mail nchris@iastate.edu enzymes or used to form the disaccharide sucrose, which is the primary sugar transported in phloem (Morvan-Betrand et al., 2001). Mono- and disaccharides formed from products of fructan hydrolysis are used for respiration and development of new foliage after defoliation (Amiard et al., 2003; MorvanBetrand et al., 1999).

Golf course greens often are double-cut or rolled to improve uniformity and increase ball roll (Nikolai, 2004). Double-cutting is clipping grasses twice in the same mowing, whereas grasses are rolled by using lightweight drums or cylinders to lightly compact the grass surface (Nikolai, 2004). Grasses also are double-cut in the overlap areas between reels in gang mowers or between subsequent passes of walk-behind mowers. These double-cut areas often develop "overlap marking" - a distinct U-shaped groove in which grasses may become discolored and exhibit reduced growth rates. It is not known if multiple cuttings limit the recuperative potential of mowed grasses more than single-cutting or rolling. The objective of this study was to quantify mowing injury by measuring levels of fructan, sucrose, glucose, fructose, and efficiency of photosystem II (PSII) in not-cut, rolled, single-cut, and double-cut grasses.

\section{Materials and Methods}

Two identical, independent experiments were repeated in time. Creeping bentgrass (Agrostis stolonifera L.) cv. L-93 seeds were planted at a rate of $24 \mathrm{~kg} \cdot \mathrm{ha}^{-1}$ in $12.7-\mathrm{cm}$ diameter by $11.4-\mathrm{cm}$ deep pots of calcareous sand and grown in a greenhouse. Particle size distribution of sand was within U.S. Golf Association guidelines (USGA, 1993). Greenhouse temperatures were 18 to $25^{\circ} \mathrm{C}$ with a photoperiod of 16 day $/ 8$ night. Natural sunlight was supplemented with high-pressure sodium lamps that provided an additional $180 \mu \mathrm{mol} \cdot \mathrm{m}^{-2} \cdot \mathrm{s}^{-1}$ of photosynthetic active radiation $(P A R)$. Measurements of $P A R$ made periodically throughout the growing cycle exceeded $400 \mu \mathrm{mol} \cdot \mathrm{m}^{-2} \cdot \mathrm{s}^{-1}$. Sand was watered daily.

Grasses were cut at $1.3 \mathrm{~cm}$ three times a week with an electric reel mower (Toro, Minneapolis, MN). A wood box with holes in the top the same diameter as the pots was built to hold pots of grass in place during mowing. The wood box had ramps on either side that allowed the electric reel mower to travel over pots and cut grasses. Because the sand in pots was level with the top of the wooden support, weight of the electric mower was evenly distributed between the wood box and the pots.

Sand media were fertilized once a week with $110 \mathrm{~mL}$ of a complete nutrient solution based on Pellet and Roberts (1963) that contained $102 \mathrm{mg} \cdot \mathrm{L}^{-1} \mathrm{~N}, 4 \mathrm{mg} \cdot \mathrm{L}^{-1} \mathrm{P}, 63 \mathrm{mg} \cdot \mathrm{L}^{-1} \mathrm{~K}$, $17 \mathrm{mg} \cdot \mathrm{L}^{-1} \mathrm{Ca}, 19 \mathrm{mg} \cdot \mathrm{L}^{-1} \mathrm{Mg}, 1.2 \mathrm{mg} \cdot \mathrm{L}^{-1} \mathrm{Fe}$, $0.25 \mathrm{mg} \cdot \mathrm{L}^{-1} \mathrm{Mn}, 0.10 \mathrm{mg} \cdot \mathrm{L}^{-1} \mathrm{~B}, 0.01 \mathrm{mg} \cdot \mathrm{L}^{-1}$ $\mathrm{Zn}$, and $0.01 \mathrm{mg} \cdot \mathrm{L}^{-1} \mathrm{Mo}$. Grasses were moved to a growth chamber at least 10 months after seeding. Grasses were mowed, watered, and fertilized like in the greenhouse. Temperature in the growth chamber was 18 to $21^{\circ} \mathrm{C}$ and a photoperiod of 16 day/8 night was maintained with cool white fluorescent lamps and incandescent bulbs that provided $550 \mu \mathrm{mol} \cdot \mathrm{m}^{-2} \cdot \mathrm{s}^{-1}$ of PAR. Grasses were acclimated in the growth chamber for at least 3 weeks before initiation of treatments. Although no formal measurements were recorded, growth rate and clipping yield of grasses were similar when grown in the greenhouse and growth chamber.

Grasses were not cut for $3 \mathrm{~d}$ before application of mowing treatments. Mowing treatments included rolling, single-cutting, and double-cutting. Grasses were rolled with a 108-kg electric greens mower without the reel engaged, whereas single-cut grasses were mowed once and double-cut grasses were mowed twice at $1.3 \mathrm{~cm}$. Harvests of plant tissue for carbohydrate analysis and measurements of efficiency of PSII were made $0,12,24,36,48$, and $60 \mathrm{~h}$ after treatment. Creeping bentgrass stubble was harvested frelected pots per treatment with a razor blade at each sampling time. The tissue was immediately frozen under liquid nitrogen and stored at $-80{ }^{\circ} \mathrm{C}$ for analysis of carbohydrates.

A portable fluorometer (PAM-101; Walz, Effeltrich, Germany) fitted with a 2-mm fiberoptic cable was used to measure lightadapted efficiency of PSII $\left(F_{m}{ }^{\prime}-F^{\prime} / F_{\mathrm{m}^{\prime}}\right)$ of individual leaf blades, where $F_{m}{ }^{\prime}$ is fluorescence in the light-adapted state and $F^{\prime}$ is initial fluorescence (Genty et al., 1989). Efficiency of PSII was measured at the adaxial tip of 10 individual light-adapted 
leaves selected at random from pots before tissue sampling.

A 0.5 - to 1.0-g sample of frozen leaf tissue was crushed under liquid $\mathrm{N}_{2}$ and suspended in $10 \mathrm{~mL}$ of high-performance liquid chromatography (HPLC)-grade water to extract soluble carbohydrates, whereas a subsample was dried in a $68{ }^{\circ} \mathrm{C}$ oven for $72 \mathrm{~h}$ for dry weight analysis. The mixture was heated to $95{ }^{\circ} \mathrm{C}$ for $30 \mathrm{~min}$ and then centrifuged at $1000 \mathrm{~g}$ for $10 \mathrm{~min}$ (Livingston, 1991). Samples were deionized by passing a $100-\mu \mathrm{L}$ aliquot of supernatant through a $1-\mathrm{mL}$ chromatography column packed from top to bottom with $120 \mu \mathrm{L}$ cation exchange resin [Dowex (Sigma Aldrich, St. Louis) $50 \times 8$ $400, \mathrm{H}+$-form], $100 \mu \mathrm{L}$ insoluble polyvinylpyrrolidone, and $120 \mu \mathrm{L}$ anion exchange resin [Amberlite (Sigma Aldrich, St. Louis) CG-400 II, formate form]. Columns were eluted twice with $250 \mu \mathrm{L}$ water. Elutants were combined and filtered through a 0.45 $\mu \mathrm{m}$ nylon filter for HPLC analysis (Amiard et al., 2003; Bachmann et al., 1994).

Water-soluble carbohydrates were analyzed by using HPLC. Sucrose, glucose, fructose, and fructans were separated on a SugarPak column $(300 \times 6.5 \mathrm{~mm}$; Waters, Milford, MA) and were isocratically eluted at $85{ }^{\circ} \mathrm{C}$ by using $0.1 \mathrm{~mm}$ disodium calcium salt of EDTA at a flow rate of $0.5 \mathrm{~mL} \cdot \mathrm{min}^{-1}$. Separated carbohydrates were identified by external standards and quantified by using a model 2410 differential refractometer (Waters).

In both experiments, treatments were completely randomized and three independent replicates were used to determine concentrations of carbohydrates at each sampling time. The general linear model of SAS (SAS Institute, Cary, NC) was used for analysis of variance of experiment, treatment, time, and their interactions. Values reported in the text and figures are representative of the highest-order interaction or main effects significant at the 0.05 level. Treatment means were separated by using Fisher's least significant difference.

\section{Results and Discussion}

Efficiency of PSII of single-cut and rolled grasses was reduced by $5 \%$ compared with not-cut grasses $12 \mathrm{~h}$ after treatment in experiment one (Fig. 1A). Double-cut grasses had a reduction in efficiency of PSII of $9 \%$ compared with not-cut grasses $12 \mathrm{~h}$ after treatment in experiment one (Fig. 1A). Twenty-four hours after treatment, efficiency of PSII of single- and double-cut grasses was reduced by $4 \%$ in Expt. 1 (Fig. 1A). In Expt. 2, single- and double-cut grasses had reductions in efficiency of PSII of $2 \%$ and $2.5 \%$, respectively, compared with not-cut grasses $12 \mathrm{~h}$ after treatment (Fig. 1B). Efficiency of PSII of single- and double-cut grasses was reduced by $3 \%$ compared with not-cut grasses $36 \mathrm{~h}$ after treatment in Expt. 2 (Fig. 1B).

A common response of many plants to wounding is to increase formation of reactive oxygen species (Orozco-Cárdenas and Ryan,

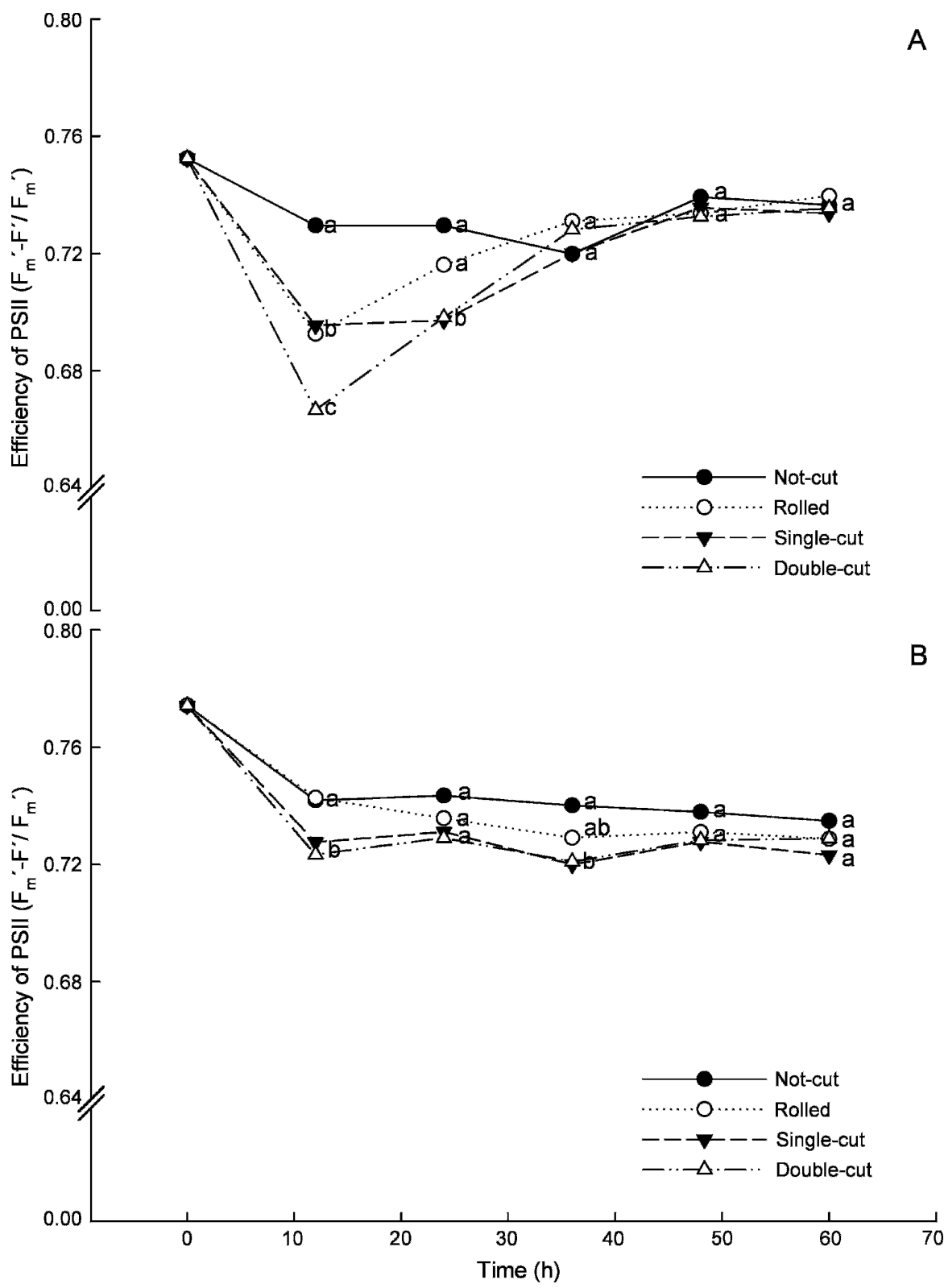

Fig. 1. Efficiency of photosystem II of not-cut, rolled, single-cut, and double-cut 'L-93' creeping bentgrass over time in Expt. 1 (A) and Expt. 2 (B). Means at each sampling time labeled with the same letter are not different at the 0.05 level by using Fisher's least significant difference to separate means. Each data point is the mean of 30 observations.

1999), which can limit the efficiency of PSII. Decreases in efficiency of PSII often are thought to be caused by an applied stress that has damaged the photosynthetic apparatus. This results in reduced efficiency of light transfer in photosynthetic electron transport (Maxwell and Johnson, 2000). Although reductions of efficiency of PSII in single- and double-cut grasses were likely too small and transient to be considered sustained photoinhibition of PSII, they nonetheless indicate a wound response. In this instance, the magnitude of reduction in efficiency of PSII indicates that double-cutting is more injurious than single-cutting.

Values reported for levels of fructan are means averaged over both experiments. Fructan level data were pooled because no inter- action between experiment and treatment existed. Fructan levels were 33\% lower in double-cut grasses compared with not-cut grasses $24 \mathrm{~h}$ after treatment. Single-cut grasses had $22 \%$ less fructan than not-cut grasses $24 \mathrm{~h}$ after treatment (Fig. 2). Thirty-six hours after treatment, fructan levels of single- and double-cut grasses were $52 \%$ and $45 \%$, respectively, lower than not-cut grasses. Fructan levels were $38 \%$ lower in double-cut grasses compared with not-cut grasses $48 \mathrm{~h}$ after treatment (Fig. 2).

Reduced levels of fructans also have been observed in mown perennial ryegrass (Lolium perenne L.) (Donaghy and Fulkerson, 1998; Sullivan and Sprague, 1943) and tall fescue (Festuca arundinacea Screb.) (Volenec, 1986). In these experiments, 
the magnitude and duration of reduction in the level of fructan were greatest in doublecut grasses indicating that multiple cuttings likely cause greater stress than single cuttings.

Changes in levels of fructose, glucose, and sucrose in response to mowing treatments were variable. No differences in levels of sucrose or fructose were observed among treatments in either study (data not shown), whereas glucose levels were reduced in single- and double-cut grasses compared with rolled and not-cut grasses (Fig. 3). Because only the main treatment effect was significant, levels of glucose were pooled over experiment and time. Levels of glucose were $31 \%$ lower in double-cut grasses compared with not-cut grasses (Fig. 3).

It is likely that hexose sugars liberated by hydrolysis of fructan after mowing main-

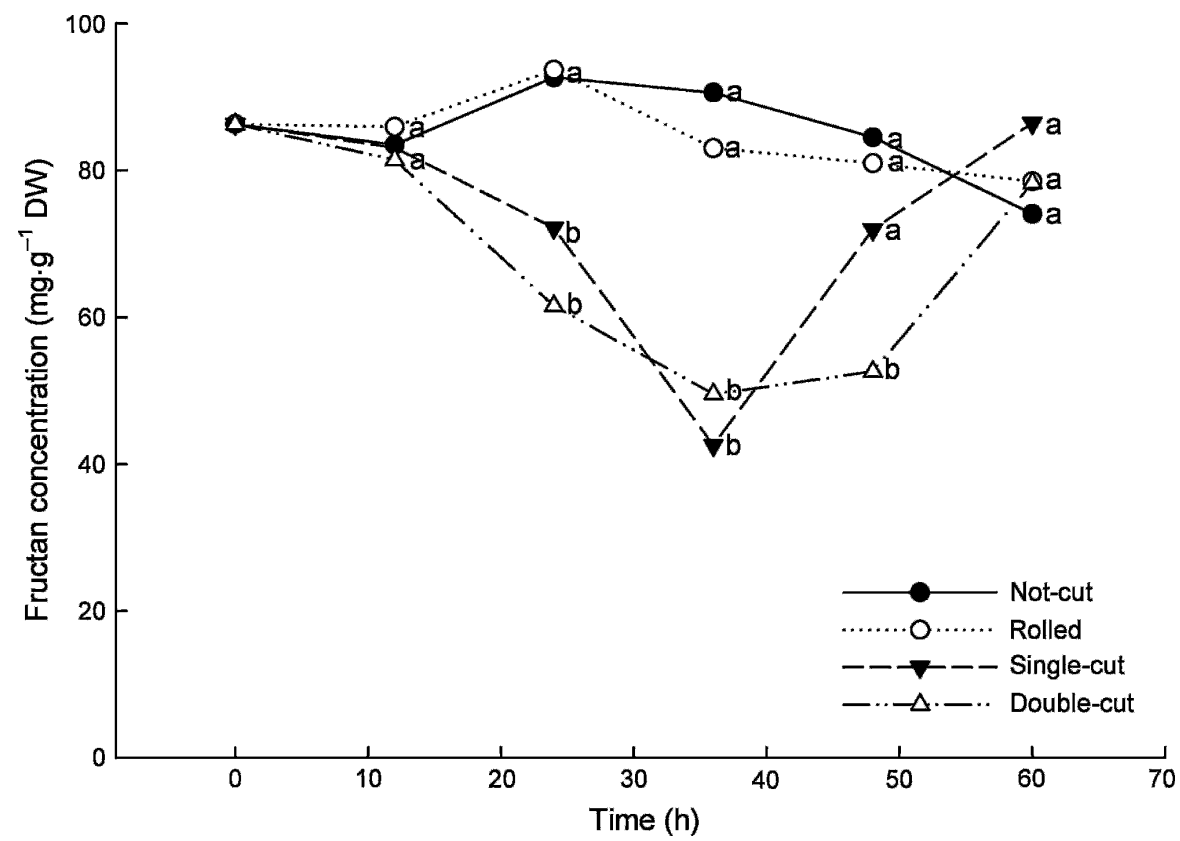

Fig. 2. Fructan concentration of not-cut, rolled, single-cut, and double-cut 'L-93' creeping bentgrass. Data averaged over experiments. Means at each sampling time labeled with the same letter are not different at the 0.05 level by using Fisher's least significant difference to separate means. Each data point is the mean of six observations.

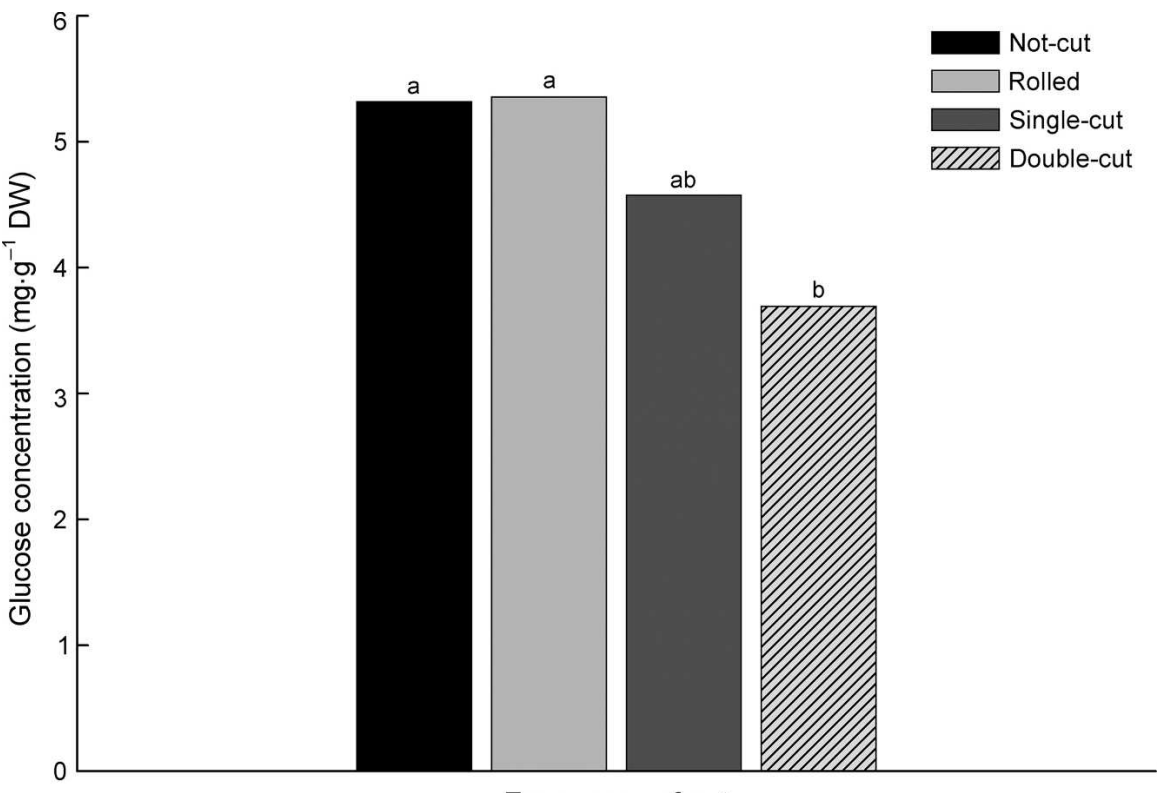

Frequency of cut

Fig. 3. Glucose concentration of not-cut, rolled, single-cut, and double-cut 'L-93' creeping bentgrass. Data averaged over experiment and time. Means labeled with the same letter are not different at the 0.05 level by using Fisher's least significant difference to separate means. Each data point is the mean of six observations.

tained levels of fructose in single- and double-cut grasses (Prud'homme et al., 1992). Likewise, sucrose likely also was resynthesized from free fructose for transport to elongating leaves to provide energy for formation of new leaf tissue (Pollack and Cairns, 1991). Amiard et al. (2003) and de Visser (1997) have demonstrated that products of fructan hydrolysis are used for respiration and development of new leaf tissue until foliage has regrown and rate of $\mathrm{CO}_{2}$ assimilation is sufficient to support plant growth and metabolism. However, steadystate labeling experiments and assays of carbohydrate metabolism enzyme rates would be needed to confirm this hypothesis.

Mowing reduced efficiency of PSII and resulted in transient decreases in the levels of fructan and glucose in creeping bentgrass. The duration and magnitude of reduction in efficiency of PSII and fructan levels were greatest in double-cut grasses, indicating that multiple cuttings may be more damaging to plant growth and development. Mowed grasses, regardless of the number of cuttings, were able to regrow sufficient leaf tissue to support plant metabolism and restore levels of reserve carbohydrates. Narra et al. (2004) often observed similar carbohydrate levels in creeping bentgrass cut at different heights in clippings collected 4 to $6 \mathrm{~d}$ after mowing. However, additional stresses like high temperature $(\mathrm{Xu}$ and Huang, 2000) that also reduce levels of reserve carbohydrates may limit recuperative potential of mown creeping bentgrass, especially when grasses are double-cut. Additional field trials should be performed that monitor levels of carbohydrates and turfgrass quality over time to support this hypothesis.

\section{Literature Cited}

Amiard, V., A. Morvan-Bertrand, J.-P. Billard, C. Huault, and M.-P. Prud'homme. 2003. Fate of fructose supplied to leaf sheaths after defoliation of Lolium perenne L.: Assessment by ${ }^{13} \mathrm{C}$-fructose labeling. J. Expt. Bot. 54:12311243.

Bachmann, M., P. Matile, and F. Keller. 1994 Metabolism of raffinose family oligosaccharides in leaves of Ajuga reptans L. Plant Physiol. 105:1335-1345.

Chatterton, N.J., P.A. Harrison, J.H. Bennet, and K.H. Asay. 1989. Carbohydrates partitioning in 185 accessions of graminae grown under warm and cool temperatures. J. Plant Physiol. 134:169-179.

Davidson, J.L. and F.L. Mithorpe. 1966. Leaf growth in Dactylis glomerata following defoliation. Ann. Bot. (Lond.) 30:173-184.

de Visser, R., H. Vianden, and H. Schnyder. 1997. Kinetics and relative significance of remobilized and current $\mathrm{C}$ and $\mathrm{N}$ incorporation in leaf and root growth zones of Lolium perenne after defoliation: assessment by ${ }^{13} \mathrm{C}$ and ${ }^{15} \mathrm{~N}$ steadystate labeling. Plant Cell Env. 20:37-46.

Donaghy, D.J. and W.J. Fulkerson. 1998. Priority for allocation of water-soluble carbohydrate reserves during regrowth of Lolium perenne. Grass Forage Sci. 53:211-218.

Genty, B., J.-M. Briantias, and N.R. Baker. 1989. The relationship between the quantum yield of photosynthetic electron transport and quenching 
of chlorophyll fluorescence. Biochim. Biophys. Acta 990:87-92.

Livingston, D.P. III. 1991. Non-structural carbohydrate accumulation in winter oat crowns before and during cold hardening. Crop Sci. 31:751-755.

Maxwell, K. and G.N. Johnson. 2000. Chlorophyll fluorescence-A practical guide. J. Expt. Bot. 51:659-668.

Morvan-Betrand, A., J. Boucaud, J. Le Saos, and M.P. Prud'homme. 2001. Roles of the fructans from leaf sheaths and from the elongating leaf bases in the regrowth following defoliation of Lolium perenne L. Planta 213:109-120.

Morvan-Betrand, A., N. Pavis, J. Boucaud, and M.P. Prud'homme. 1999. Partitioning of reserve and newly assimilated carbon in roots and leaf tissues of Lolium perenne during regrowth after defoliation: Assessment by ${ }^{13} \mathrm{C}$ steady-state labeling and carbohydrate analysis. Plant Cell Environ. 22:1097-1108.

Narra, S., T.W. Fermanian, J.M. Swiader, T.B. Voigt, and B.E. Branham. 2004. Total non- structural carbohydrate assessment in creeping bentgrass at different mowing heights. Crop Sci. 44:908-913.

Nikolai, T.A. 2004. Rollin', rollin', rollin'. Golf Course Management. 72:121-124.

Orozco-Cárdenas, M.L. and C.A. Ryan. 1999 Hydrogen peroxide is generated systemically in plant leaves by wounding and systemin via the octadecanoid pathway. Proc. Natl. Acad. Sci. USA 96:6553-6557.

Parsons, A.J., E.L. Leafe, B. Collet, and W. Stiles. 1983. The physiology of grass production under grazing. I. Characteristics of leaf and canopy photosynthesis of continuously grazed swards. J. Appl. Ecol. 20:117126.

Pellet, H.M. and E.C. Roberts. 1963. Effects of mineral nutrition on high temperature induced growth retardation of Kentucky bluegrass. Agron. J. 55:473-476.

Pollack, C.J. and A.J. Cairns. 1991. Fructan metabolism in grasses and cereals. Annu. Rev. Plant Physiol. Plant Mol. Biol. 42:77-101.
Prud'homme, M.P., B. Gonzalez, J.P. Billard, and J. Boucad. 1992. Carbohydrate content, fructan and sucrose enzyme activities in roots, stubble and leaves of ryegrass (Lolium perenne L.) as affected by source/sink modification after cutting. J. Plant Physiol. 140:282-292.

Sullivan, J.T. and V.G. Sprague. 1943. Composition of the roots and stubble of perennial ryegrass following partial defoliation. Plant Physiol. 18:656-670.

U.S. Golf Association (USGA). 1993. USGA recommendations for a method of putting green construction. USGA Green Section Record 31: $1-33$.

Volenec, J.J. 1986. Nonstructural carbohydrates in stem base components of tall fescue during regrowth. Crop Sci. 26:381-385.

White, L.M. 1973. Carbohydrate reserves of grasses: A review. J. Range Manage. 26:13-18.

$\mathrm{Xu}, \mathrm{Q}$. and B. Huang. 2000. Effects of differential air and soil temperature on carbohydrate metabolism in creeping bentgrass. Crop Sci. 40:1368-1374. 